\title{
Implications of English as an International Language
}

\section{for Language Pedagogy}

\author{
Kim Hua Tan ${ }^{1}$, Atieh Farashaiyan ${ }^{2}$, Rahman Sahragard ${ }^{2} \&$ Fatemeh Faryabi $^{2}$ \\ ${ }^{1}$ Faculty of Social Sciences and Humanities, Universiti Kebangsaan Malaysia \\ ${ }^{2}$ Department of Foreign Languages \& Linguistics, Shiraz University, Iran \\ Correspondence: Kim Hua Tan, Faculty of Social Sciences and Humanities, Universiti Kebangsaan Malaysia. E-mail: \\ kimmy@ukm.edu.my
}

Received: October 8, 2019

Accepted: November 10, 2019

Online Published: November 13, 2019

doi:10.5430/ijhe.v9n1p22

URL: https://doi.org/10.5430/ijhe.v9n1p22

\begin{abstract}
The position of the English language in the world has recently underwent an enormous shift. The global spread of English has altered its status from being a homogeneous and standard language spoken by a few powerful countries into an international language or lingua franca spoken by a wide variety of speakers around the world (Llurda, 2004). The unprecedented global demand, use, and appropriation of English as an international language (EIL) necessitates a profession-wide response to English language learning, teaching, teacher education, assessment, and policy. The international status of English and increase in the number of EIL learners require a teaching agenda that incorporates pedagogical approaches that teach English based on EIL principles (Matsuda, 2003). The current study attempts to discuss the implications of EIL on issues related to language pedagogy, such as culture and intercultural competence in EIL, native-like competence, English teachers in the EIL pedagogy, language assessment in EIL and EIL teacher education. The studies show that EIL as a means of intercultural communication in a wide range of contexts calls for a reconceptualisation of language pedagogy It is concluded that despite the extensive discussions on the role of students' first language culture for EIL learners, English textbooks and classrooms continue to rely on the target culture and ignore the students' own culture. Therefore, EIL has yet to be fully incorporated language education despite extensive studies that have been conducted on its role.
\end{abstract}

Keywords: English, implications, international language, language pedagogy

\section{Introduction}

The position of the English language in the world has recently underwent an enormous shift. Much literature has been written about what English as an International Language (EIL) actually is (e.g. Alsagoff et al., 2012; Matsuda, 2003; McKay and Brown, 2016; Sharifian, 2009), ranging from a view of EIL as the many varieties of English that are spoken today to the use of English by second language speakers of English. Thus, EIL is viewed both as a type of English and as a way of using English (Cameron \& Galloway, 2019).

In addition, the global spread of English has altered its status from being a homogeneous and standard language spoken by a few powerful countries into an international language or lingua franca spoken by a wide variety of speakers around the world (Llurda, 2004; Galloway \& Rose, 2017). Crystal (1997) stated that "if there is one predictable consequence of globalization of a language, it is that nobody owns it anymore" (p. 2). Various studies (e.g. Llurda, 2017; Marlina, 2018; Schuttz, 2019) have widely argued that English does not belong only to native-speaking communities because the number of people who currently speak English as a second/foreign language exceeds that of native English speakers. Seidlhofer (2003) asserted that "English is being shaped at least as much by its nonnative speakers as by its native speakers" (p. 339).

Therefore, native speakers in English speaking communities (e.g. the US and the UK) form a small group compared with English users across the globe and cannot judge what is appropriate in international communication (Clyne $\&$ Sharifian, 2008). Graddol (1997) concluded that the future of English is not shaped by its native speakers but by those who use English as an international language (EIL). Additionally, the global expansion of English has a significant on the manner by which this language should be conceptualised and taught (Seidlhofer, 2004). "The unprecedented global demand, use, and appropriation of English as an international language (EIL) necessitates a 
profession-wide response to English language learning, teaching, teacher education, assessment, and policy" (Selvi, 2013, p. 42). The international status of English and increase in the number of EIL learners require a teaching agenda that incorporates pedagogical approaches that teach English based on EIL principles (Matsuda, 2003).

\subsection{Statement of the Problem}

The globalization of English renders the language into a global lingua franca and an international language. Therefore, it has realistic implications for teaching English as an International Language (TEIL). English as an International Language (EIL) is more than a 'language' per se. It has increasingly been conceptualised as a framework or a paradigm, developed alongside the glocalization of English, and it is a multicultural way of thinking, doing and being. EIL recognizes English variation and varieties, and it is time to introduce EIL awareness, literacy, and competence into language education (Sharifian, 2017).

Despite the proliferation of publications on teaching English as an international language (EIL), the diffusion of these concepts into the world of English Language Teaching has been slow and incomplete. There is some wariness among educators about the teaching of EIL, with no consensus regarding the implications of EIL on issues related to language pedagogy ( $\mathrm{Si}, 2019 ; \mathrm{Xu}, 2018)$. Therefore, to tackle the issue, this paper looks at some of the research on issues related to language pedagogy, such as intercultural competence, native-like competence, assessment in EIL and EIL teacher education.

\subsection{Objective of the Study}

The purpose of this article is to (1) grapple with defining the constructs of EIL, and (2) elaborate on what these constructs mean for pedagogy. In particular, this research will discuss the implications of EIL on issues related to language pedagogy, such as intercultural competence, native-like competence, assessment in EIL and EIL teacher education

\section{Literature Review}

Smith (1976) proposed the notion of 'English as an International Auxiliary Language' (EIAL) in the 1970s, defining an 'international language' as one "which is used by people of different nations to communicate with one another" (p. 38). He made a number of assumptions regarding the relationship of an 'international language' and culture. These include: (1) Learners do not need to internalize the cultural norms of native speakers of that language. (2) The ownership of an international language becomes 'de-nationalised'. (3) The educational goal of learning it is to enable learners to communicate their ideas and culture to others (Smith, 1976, pp. 38-42). At the beginning of the 21st century, McKay (2002, pp. 12) revisited the notion of EIL, and put forward the following assumptions. As an international language: (1) English is used both in a global sense for international communication and in a local sense as a language of wider communication within multilingual societies. (2) The use of English is no longer connected to the culture of Inner Circle countries. (3) English becomes embedded in the culture of the country in which it is used. (4) One of the primary functions of EIL is to enable speakers to share their ideas and culture with others.

Sharifian (2009) proposes that EIL has become a new 'paradigm' for thinking, research and practice. In addition, Marlina (2014, pp. 4-5) unpacks the notion of EIL further by clarifying that EIL, as a paradigm, "recognizes the international functions of English and its use in a variety of cultural and economic arenas by speakers of English from diverse lingua-cultural backgrounds who do not speak each other's mother tongues", and that the EIL paradigm 'recognizes and embraces all varieties of English at national, regional, social, and idiolectal levels in all circles as equal'. Explorations of teaching EIL have so far largely been at the level of theories rather than practices. Therefore it remains a question as how EIL is defined and the issues related to it. Mckay (2018) has included intercultural competence, native-like competence, assessment in EIL and EIL teacher education as its main components which are discussed below.

\subsection{Culture in EIL}

Culture is an indispensable component of learning and teaching a language (Byram, 1997; Dogancay-Aktuna \& Hardman, 2018; Kramsch, 1993). The teaching of culture in the EIL context has been the subject of intense debate in the research on teaching English as a foreign language(Tan \& Farashaiyan, 2016). Traditionally, the concept of culture in foreign language teaching was conceptualised within the inner circle norms. However, the current global spread of English and use of this language as a means of international communication in multilingual and multicultural contexts have resulted in intercultural communication veering away from the native speaker norms (Baker, 2011) and intercultural communication becoming the focus of EFL education (Moeller\& Nugent, 2014). 
Numerous studies (e.g. Marlina, 2014; Seidlhofer, 2005; Sharifian, 2009; Xu, 2017b) that argue for EIL and English as a lingua franca have continuously proposed that native speaker norms cannot be applied to the EIL context. Canagarajah (2013) maintained that the globalisation of English has resulted in this language becoming no longer homogeneous that contains local norms. Instead, English should be conceptualised as a heterogeneous language with multiple norms that work differently in various contexts. Given that English no longer belongs to the inner circle countries, this language is no longer associated with the culture of native speaker communities (Baker, 2009; Rai \& Deng, 2016).

Language teaching textbooks mainly represent culture through the target language because they are published in inner circle countries. Moreover, such cultural contents are believed to increase students' motivation for learning English. However, EIL learners study English for intercultural communications to convey information on their own culture and country to others (McKay, 2003). Kirkpatrick (2014) contended that the EIL pedagogy should aim to enhance language learners' intercultural competence rather than basing itself on native speakers' culture. In the current globalised world, English is extensively used amongst people in the expanding circle rather than the inner circle countries; hence, an EIL pedagogy that focuses on intercultural competence of language learners is required for successful communication with people from different linguistic and cultural backgrounds (Sharifian, 2014).

Honna and Takeshita (2014, p. 68) explained that "English is bound to reflect the world's various cultures". Moreover, the EIL pedagogy adds an intercultural dimension to its content and produces learners who are linguistically competent and able to effectively move across cultural boundaries and between different identities and avoid forming stereotypes of speakers from other cultures with different backgrounds and world views (Byram, Gribkova, \& Starkey, 2002). That is, successful communication entails transcending a monolingual context of use with a fixed culture and raising learners' awareness of multicultural and multilingual contexts of English language use (Baker, 2011). To raise learners' intercultural awareness, Nugent and Catalano (2015) discussed that teachers should provide students with the opportunity to reflect on their attitudes towards the target cultures and guide them through the process of practicing intercultural communication by exploring the perspectives and practices of other cultures.

\subsubsection{Research Conducted on Culture in EIL}

Several studies have investigated how culture is represented in EFL textbooks in the EIL context. Aliakbari (2005) assessed how culture is represented in English language teaching (ELT) in Iran, specifically through high school textbooks. The findings of his study indicated that the representation of culture in textbooks is (1) shallow and superficial, (2) does not present comprehensive information on culture, such as norms, values and beliefs, and (3) does not prepare students for intercultural communication.

Shin, Eslami and Chen (2011) explored how local and international cultures are represented in current international ELT textbooks. They analysed the cultural content of seven series of internationally distributed ELT textbooks and revealed that despite the diversity of cultural aspects in each textbook series, inner circle cultural content remained dominant in the majority of the textbooks. The aforementioned research also showed that cultural presentation was mainly provided at the knowledge-oriented level and did not engage learners through reflections. Chinh (2013) investigated learners' perspective on cultural diversity in ELT in the EIL context. Students had a positive attitude towards cultural diversity and believed that will enhance their intercultural competence.

Rashidi and Meihami (2016) explored the cultural content of ELT textbooks in inner, outer and expanding circle countries. The aforementioned study found a difference between the cultural content of ELT textbooks in the three circles. The ELT textbooks of the inner circle represent first and second language cultural contents, whereas those of the expanding circle present more first language and international cultural contents. Moreover, the ELT textbooks of the outer circle present first and second languages and international cultural content.

\subsection{Native-like Competence in EIL}

The shift in the status of English from a standard language to EIL has significantly influenced language teaching and learning globally. Consequently, a controversial line of research has been developed on the role of native speakers as model in language teaching (e.g. Cook, 1999; Kramsch, 1997). English is in transition and the current number of non-native speakers who use English for international communication exceeds that of native speakers (Graddol, 1997). The increasing growth of EIL has changed learners' linguistic needs and goals. That is, the major goal of language learners is no longer to achieve native-like accent and communicate with native speakers for learning English. 
Currently, learners aspire successful international communication with other non-native speakers from different linguistic and cultural backgrounds (Jenkins, 1998). Thus, EIL learners should not be considered foreign speakers of the English language but as international speakers who are members of an international community (Jenkins, 2002). The idealisation of the native speaker has generally been criticised by scholars who advocate English as a lingua franca, EIL and world Englishes. Cook (1997) posited that language pedagogy should go beyond the native speaker as the correct model and be built around second/foreign language speaker models and the students' first language, instead of aiming to reach the state of monolingual native speakers. The reason is that both aspects are linguistically and cognitively different from native speakers.

In the 1970s, the emphasis placed on communicative competence assigned an authoritative role to the native speakers and learners had to imitate them in many areas of language proficiency, such as culture, pronunciation and communication skills (Kramsch, 1997). However, Kramsch explained that the assumption of a unitary native speaker is false and unreasonable because native speakers do not fully adhere to the rules of standard language and their speech includes regional and class-related features. Moreover, the substantial increase in the number of individual speakers who are learning English as a second/foreign language has led to the demise of native speakers (McKay, 2003). EIL speakers learn English for specific and limited purposes compared with immigrants who use English in all situations. EIL learners may use English in multilingual contexts or to share information on their own country and culture for occupational and economic purposes (McKay, 2003).

Stern (1983) stated that the idea of native-like competence is unwarranted because many EIL learners use English in concomitant to other languages and also have reasons for learning English that are relatively different from monolingual English speakers. Thus, achieving native-like competency is a disputable stance. Additionally, conceptualising ELT within the inner circle norms may work for learners who learn English as a second language, the aim of whom is to communicate within the native speaker communities. However, this curriculum is insufficient for EIL learners who use English for different purposes in different ways and in a variety of contexts (as cited in Matsuda, 2003). Accordingly, numerous studies (Cook, 1999) have argued for fostering multi-competence in language learners and a translingual pedagogy that gives importance to communicative effectiveness and negotiations of meaning (Canagarajah, 2005; Kafle, 2013).

\subsubsection{Research on Native-like Competence in EIL}

Some studies have investigated teachers and learners' attitudes towards native-like accents and competence in the EIL context and the globalised world. Pishghadam and Sabouri (2011) probed English learners' attitudes towards different varieties of English and native English accents. They were presented with a text read in different English varieties. They viewed the American accent as significantly better that the other accents and believed that native-speaking teachers have priority over non-native teachers.

Buckingham (2014) examined Omani students' attitudes towards English teachers' accents in the Gulf. The results revealed that they showed preference when they knew that the teacher was from the UK, although they also responded favourably to Arabic native speakers as models for their own learning path. Kaur and Raman (2014) explored how non-native speakers of English viewed non-native accents in relation to the accents of native speakers. Researchers used a questionnaire and found that teachers perceived native-speaker accents as more correct, acceptable for international communication, pleasant and familiar than non-native English accents.

In another study, Khatib and Monfared (2017) studied English teachers' attitudes towards pronunciation issues and varieties of English in three circles of world Englishes. The findings indicated that native teachers positively viewed pronunciation and varieties of English and accepted different varieties of this language. Indian teachers indicated highly positive attitudes towards their Indian English even though they were in favour of British English. By contrast, Iranian EFL teachers showed prejudice against other English varieties and generally favoured Native American English pronunciation.

\subsection{English Teachers in the EIL Pedagogy}

The reconceptualisation of English as an international language has changed the nature of the English language and critically altered the role of teachers from imitators of native speakers (Dewey \& Patsko, 2017; McKay, 2003) and ambassadors of the target culture (Llurda, 2004) to promoters of intercultural competence and different English varieties and critical practitioners (Renandya, 2012). McKay (2002) expressed that teachers play a critical role in the implementation of the new EIL pedagogy. To practice EIL in their classroom, teachers should firstly be aware of the EIL principles and current status of English and hold positive attitudes towards them (Matsuda, 2003; Renandya, 2012). 
In this regard, Bayyurt and Sifakis (2017) proposed an EIL-aware teacher education model that promotes teachers' critical awareness of how EIL works and attempts to change their perspective towards EIL. In this model, teachers are firstly provided with comprehensive information on the global spread of English and its pluricentric nature. Thereafter, they are informed of the potential challenges that may arise in their teaching as a result of EIL. Lastly, the teachers are asked to engage in an action plan that assists them in incorporating EIL into their teaching and experimenting with their knowledge of EIL. McKay (2003) explained that the EIL pedagogy should be governed by a set of assumptions and principles that are totally distinct from the principles of ELT and, as Brown and Peterson (1997, p. 44) asserted, "in line with the sociolinguistic realities of the spread of English as an international language".

Thus, changes should be made in the pedagogy of English teaching and teacher education. Traditionally native-like competence was the norm and ultimate goal of language learning, thereby resulting in the preference for native speaking teachers over non-native teachers (Llurda, 2017). However, English globalisation has resulted in English teachers becoming more in demand than ever, although native-speaking teachers only form a small group that definitely cannot meet this extensive need (Llurda, 2017; McKay, 2003). Moreover, native teachers have numerous advantages over non-native teachers, thereby assisting EIL learners in the learning process (e.g. Llurda, 2004; McKay, 2003). Matsuda (2003) maintained that "EFL teachers should not be defined only in terms of their non-nativeness. They must be given ongoing opportunities, both during and after the program, to evaluate their weaknesses and strengths, to overcome their weaknesses, and to make the most of their strengths" (p. 725). Therefore, non-native teachers are no longer the minority in the field of EIL teacher education.

\subsubsection{Research Conducted on English Teachers in EIL}

Jenkins (2005) probed the role of teacher identity and attitudes in implementing an EIL approach to teaching pronunciation. Accordingly, all the participants exhibited uncertainty with regards to their attitudes towards their own English accent. Additionally, the majority of the teachers accepted EIL theoretically but not practically and stated that it was not possible to teach EIL pronunciation. The aforementioned study concluded that teachers from the expanding circle were ambivalent in using their accented English to express their first language identity or membership in an international community.

In another research, Tomak and Kocabas (2013) explored the perspectives of prospective English teachers on the status of English as a lingua franca and their awareness of it in their ELT programs. The results indicated that teachers have ambivalent attitudes towards dealing with EIL. Although the aforementioned research asserted that knowledge of different English varieties leads to successful communication with EIL speakers, the majority of the teachers, particularly those in urban state universities, believed that they should continue to use Standard English and practice correct grammar and pronunciation. They also stated the difficulty in teaching Turkish culture using English.

Nguyen (2017) studied on whether non-native English teachers agreed with the native speaker model and investigated the impact of teacher education on teachers' attitudes and beliefs on native-speaker models. The results of the aforementioned study indicated that providing relevant input to teachers positively influences their beliefs on the multiple varieties and pluricentric nature of English. Subsequently, teachers were able to critically reflect on and discuss the characteristics of native and non-native speakers.

Lee, Lee and Drajati (2018) examined pre-service English teachers' perceptions of EIL in Indonesia and South Korea. They found that Indonesian pre-service teachers had greater potential to include effective cross-cultural communicative strategies in their teaching compared with South Korean teachers and manifested a high degree of ownership over their own English accent. South Korean pre-service teachers acknowledged the non-native varieties of English, although they were apprehensive about using non-native English accents in listening classes.

\subsection{Language Assessment in EIL}

English language teaching and assessment were previously driven by a standard language ideology, which proposed that the standard language (e.g. British or American) used by native speakers should be followed as the norm in language pedagogy (Canagarajah, 2013). However, the validity of this assumption has been questioned in light of Kachru \& Nelson's (1996) expanding circle. That is, English functions as a foreign language for international communication amongst many English speakers. Thus, the overarching changes in the uses and users of English demand the reconceptualisation of English language teaching and assessment (Lowenberg, 2002; McKay \& Brown, 2016).

Accordingly, EIL speakers in the outer and expanding circles should no longer be required to remain with the native speaker norms (Jenkins, 2006). In the current EIL pedagogy, language testing should be pertinent to the expanding 
circle context and EIL learners' linguistic and communicative needs (Jenkins, 2006). In traditional language testing, two standard varieties of native-speaker English (i.e. American and British English) were the norms when assessing English proficiency (Lowenberg, 2002). "However, the fundamentally changed landscape of EIL requires a critical examination of the established assessment practices" (Hu, 2012, p. 123).

Canagarajah (2013) argued that language assessment should veer away from measuring proficiency on the basis of the standard varieties of the inner circle towards assessing negotiation, which is more relevant to what is required in the EIL contexts. That is, the appropriate interpersonal strategies are used in communicative activities. Additionally, Shohamy (2017) maintained that English is a heterogeneous language with multiple and variable norms for different social and multilingual interactions, which proficient EIL speakers have to be aware of to successfully communicate with other English speakers from different linguistic and cultural backgrounds.

Sharifian (2009) and Marlina (2014) stated that the EIL paradigm shift views English as a pluricentric language and does not rely on a particular variety of English, although all varieties are acknowledged for international communications and intercultural relationships. These perceptions implied that "we should focus on language awareness rather than grammatical correctness in a single variety; strategies of negotiation rather than mastery of product-orientated rules; pragmatics rather than competence" (Canagarajah, 2013, p. 8).

\section{Conclusion}

Given the current globalisation, bilingual speakers who are learning English as an additional language outnumber its native speakers (Matsuda, 2003). Traditionally, the goal of bilingual learners of English was believed to be reaching native-like fluency in English. Brown and Peterson (1997) explained that learners fully acquire the target language through the culture of the native language. However, learners generally aim to use English for intercultural communication rather than reaching native-like competency (McKay, 2012).

Therefore, McKay (2018) stated that language professionals should shift from focusing on native speaker models to obtaining a realistic picture of how English is used for different purposes in various intercultural relationships among EIL learners. Alternatively, EIL as a means of intercultural communication in a wide range of contexts calls for a reconceptualisation of language pedagogy (Leung \& Brian, 2012; Xu, 2017a).

However, the studies reviewed in the previous sections indicate that the principles of EIL are inadequately considered in language pedagogy. Numerous teachers in various countries continue to perceive British and American English as the only valid and acceptable varieties. Although they believe that EIL is beneficial for successful intercultural communication, they are still hesitant to practice EIL (e.g. Kaur \& Raman, 2014; Khatib \& Monfared, 2017). Additionally, students are unaware of their status as EIL learners and continue to view Standard English as the appropriate variety of English and prefer native or native-like teachers (Buckingham, 2014; Pishghadam \& Sabouri, 2011). Despite the extensive discussions on the role of students' first language culture for EIL learners, English textbooks and classrooms continue to rely on the target culture and ignore the students' own culture (e.g. Aliakbari, 2005; Rashidi \& Meihami, 2016). Therefore, EIL has yet to be fully incorporated language education despite extensive studies that have been conducted on its role.

\section{Acknowledgements}

The authors acknowledge the help of the Malaysian Ministry of Education (Research Grant FRGS/1/2018/SS09/UKM/02/1 in funding of work leading to the publication of this paper.

\section{References}

Aliakbari, M. (2005). The Place of Culture in Iranian EL T Textbooks at the High School Level. Pan-Pacific Association of Applied Linguistics (PAAL), 9(1), 163-179.

Alsagoff, L., Mckay, S. L., Hu, G., \& Renandya, W. A. (Eds.). (2012). Principles and Practices for Teaching English as an International Language. New York and London: Routledge. https://doi.org/10.4324/9780203819159

Baker, W. (2009). The cultures of English as a lingua franca. Tesol Quarterly, 43(4), 567-592. https://doi.org/10.1002/j.1545-7249.2009.tb00187.x

Baker, W. (2011). Intercultural awareness: Modelling an understanding of cultures in intercultural communication through English as a lingua franca. Language and Intercultural Communication, 11(3), 197-214. https://doi.org/10.1080/14708477.2011.577779

Bayyurt, Y., \& Sifakis, N. (2017). Foundations of an EIL-aware teacher education. Preparing teachers to teach English as an international language, 53, 1. https://doi.org/10.21832/9781783097036-003 
Brown, K., \& Peterson, J. (1997). Exploring conceptual frameworks: Framing a World Englishes paradigm. In $L$. Smith \& M. L. Forman (Eds.), World Englishes 2000 (pp. 32-47). Honolulu: University of Hawai'i \& East-West Center.

Buckingham, L. (2014). Attitudes to English teachers' accents in the G ulf. International Journal of Applied Linguistics, 24(1), 50-73. https://doi.org/10.1111/ijal.12058

Byram, M. (1997). Teaching and assessing intercultural communicative competence. Multilingual Matters.

Byram, M., Gribkova, B., \& Starkey, H. (2002). Developing the intercultural dimension in language teaching. A practical introduction for teachers. Strasbourg: Council of Europe.

Cameron, A., \& Galloway, A. (2019). Local Thoughts on Global Ideas: Pre-and In-service TESOL Practitioners' Attitudes to the Pedagogical Implications of the Globalization of English. RELC Journal, 50(1), 45-56. https://doi.org/10.1177/0033688218822853

Canagarajah, A. S. (2005). Reclaiming the local in language policy and practice. Routledge.

Canagarajah, A. S. (2013). Redefining proficiency in global English. In Zacharias, N. T., \& Manara, C. (Eds.). Contextualizing the pedagogy of English as an international language: Issues and tensions, Cambridge Scholars Publishing.

Chinh, N. D. (2013). Cultural Diversity in English Language Teaching: Learners' Voices. English Language Teaching, 6(4), 1-7. https://doi.org/10.5539/elt.v6n4p1

Clyne, M., \& Sharifian, F. (2008). English as an international language. Australian Review of Applied Linguistics, 31(3), 28-1. https://doi.org/10.2104/aral0828

Cook, V. (1997). Monolingual Bias in Second Language Acquisition Research by Vivian Cook Monolingual Bias in Second Language Acquisition Research. Revista canaria de estudios ingleses, 34, 35-50.

Cook, V. (1999). Going beyond the native speaker in language teaching. TESOL Quarterly, 33, 185-209. https://doi.org/10.2307/3587717

Crystal, D. (1997). English as a Global Language. Cambridge: Cambridge University Press. https://doi.org/10.1017/s0047404599301044

Dewey, M., \& Patsko, L. (2017). ELF and teacher education. In J. Jenkins, M. Dewey, \& W. Baker (Eds.), The Routledge handbook of English as a lingua franca Abingdon: Routledge. https://doi.org/10.4324/9781315717173-36

Dogancay-Aktuna, S., \& Hardman, J. (2018). Teaching of English as an International Language in Various Contexts: Nothing is as Practical as Good Theory. RELC Journal, 49(1), 74-87. https://doi.org/10.1177/0033688217750642

Galloway, N., \& Rose, H. (2017). Incorporating Global Englishes into the ELT classroom. ELT Journal, 72(1), 3-14. https://doi.org/10.1093/elt/ccx010

Graddol, D. (1997). The future of English? London: British Council.

Honna, N., \& Takeshita, Y. (2014). English as an international language and three challenging issues in English language teaching in Japan. In The pedagogy of English as an International Language (pp. 65-77). Springer, Cham. https://doi.org/10.1007/978-3-319-06127-6_5

Hu, G. (2012). Assessing English as an International Language: Guangwei Hu. In Principles and practices for teaching English as an international language (pp. 131-151). Routledge.

Jenkins, J. (1998). Which pronunciation norms and models for English as an International Language? ELT journal, 52(2), 119-126. https://doi.org/10.1093/elt/52.2.119

Jenkins, J. (2002). A sociolinguistically based, empirically researched pronunciation syllabus for English as an international language. Applied linguistics, 23(1), 83-103. https://doi.org/10.1093/applin/23.1.83

Jenkins, J. (2005). Implementing an international approach to English pronunciation: The role of teacher attitudes and identity. Tesol Quarterly, 39(3), 535-543. https://doi.org/10.2307/3588493

Jenkins, J. (2006). Current perspectives on teaching world Englishes and English as a lingua franca. TESOL quarterly, $40(1), 157-181$. https://doi.org/10.2307/40264515 
Kachru, B. B., \& Nelson, C. L. (1996). World Englishes. Sociolinguistics and language teaching, 11, 71-102. https://doi.org/10.1017/cbo9780511551185.006

Kafle, M. (2013). Reconceptualizing EIL Pedagogy: From Mastery to Successful Negotiation. In Zacharias, N. T., \& Manara, C. (Eds.). Contextualizing the pedagogy of English as an international language: Issues and tensions, Cambridge Scholars Publishing.

Kaur, P., \& Raman, A. (2014). Exploring native speaker and non-native speaker accents: The English as a Lingua Franca perspective. Procedia-Social and Behavioral Sciences, 155, 253-259. https://doi.org/10.1016/j.sbspro.2014.10.288

Khatib, M., \& Monfared, A. (2017). Exploring English Teachers' attitudes towards Pronunciation issues and varieties of English in three circles of world Englishes. Applied Research on English Language, 6(2), 213-236. https://doi.org/10.22108/are.2017.21349

Kirkpatrick, A. (2014). English as a medium of instruction in East and Southeast Asian universities. In Dynamic ecologies (pp. 15-29). Springer, Dordrecht. https://doi.org/10.1007/978-94-007-7972-3_2

Kramsch, C. (1993). Context and culture in language teaching. Oxford University Press. https://doi.org/10.1017/s0272263100013619

Kramsch, C. (1997). Guest column: The privilege of the nonnative speaker. Publications of the Modern language Association of America, 359-369.

Lee, J. S., Lee, K., \& Drajati, N. A. (2018). Preservice English teachers' perceptions of English as an international language in Indonesia and Korea. Journal of Multilingual and Multicultural Development, 40(3), pp.230-243. https://doi.org/10.1080/01434632.2018.1503669

Leung, C., \& Brian, V. S. (2012). Linking EIL and Literacy. Principles and practices for teaching English as an International Language (pp. 93-111). Routledge.

Llurda, E. (2004). Non-native- ${ }^{-}$speaker teachers and English as an International Language International Journal of Applied Linguistics, 14(3), 314-323. https://doi.org/10.1111/j.1473-4192.2004.00068.x

Llurda, E. (2017). English language teachers and ELF. In J. Jenkins, M. Dewey, \& W. Baker (Eds.), The Routledge handbook of English as a lingua franca (pp. 518-528). Abingdon: Routledge. https://doi.org/10.4324/9781315717173-42

Lowenberg, P. H. (2002). Assessing English proficiency in the expanding circle. World Englishes, 21(3), 431-435. https://doi.org/10.1111/1467-971X.00261

Marlina, R. (2014). The pedagogy of English as an international language (EIL): More reflections and dialogues. In The pedagogy of English as an International Language (pp. 1-19). Springer, Cham. https://doi.org/10.1007/978-3-319-06127-6_1

Marlina, R. (2018). Teaching English as an International Language: Implementing, Reviewing, and Re-Envisioning World Englishes in Language Education. Abingdon: Routledge. https://doi.org/10.4324/9781315315768

Matsuda, A. (2003). Incorporating World Englishes in teaching English as an international language. TESOL Quarterly, 37, 719-729. https://doi.org/10.2307/3588220

Matsuda, A. (2012). Teaching English as an international language: principles and practice. Clevedon, UK: Multilingual Matters. https://doi.org/10.21832/9781847697042-002

McKay, S. L. (2002). Teaching English as an international language: Rethinking goals and approaches. Oxford, England: Oxford University Press. https://doi.org/10.1017/s0272263104231059

McKay, S. L. (2003). Toward an appropriate EIL pedagogy: Re-examining common ELT assumptions. International journal of applied linguistics, 13(1), 1-22. https://doi.org/10.1111/1473-4192.00035

McKay, S. L. (2012). Principles of Teaching English as an International Language: Sandra Lee McKay. In Principles and practices for teaching English as an international language (pp. 36-54). Routledge. https://doi.org/10.21832/9781847697042-007

McKay, S. L. (2018). English as an international language: What it is and what it means for pedagogy. RELC Journal, 49(1), 9-23. https://doi.org/10.1177/0033688217738817 
McKay, S. L. \& Brown, J. D. (2016) Teaching and Assessing EIL in Local Contexts Around the World. New York: Routledge. https://doi.org/10.1080/1554480x.2016.1209821

Moeller, A. K., \& Nugent, K. (2014). Building intercultural competence in the language classroom.

Nguyen, M. X. N. C. (2017). TESOL Teachers' Engagement with the Native Speaker Model: How Does Teacher Education Impact on Their Beliefs? RELC Journal, 48(1), 83-98. https://doi.org/10.1177/0033688217690066

Nugent, K., \& Catalano, T. (2015). Critical cultural awareness in the foreign language classroom. The NECTFL Review, 75(1), 15-30. https://doi.org/10.1007/978-3-319-02325-0_16-1

Pishghadam, R., \& Sabouri, F. (2011). A Quantitative Survey on Iranian English Learners' Attitudes toward Varieties of English: World English or World Englishes? English Language and Literature Studies, 1(1), 86. https://doi.org/10.5539/ells.v1n1p86

Rai, L., \& Deng, C. (2016). Glocalisation and English language education in Chinese context. Globalization, Societies and Education, 14(1), 127-144. https://doi.org/10.1080/14767724.2014.980226

Rashidi, N., \& Meihami, H. (2016). Hidden curriculum: An analysis of cultural content of the ELT textbooks in inner, outer, and expanding circle countries. Cogent Education, 3(1), 1212455. https://doi.org/10.1080/2331186X.2016.1212455

Renandya, W. A. (2012). Teacher roles in EIL. The European journal of applied Linguistics and TEFL, 1(2), 65-80.

Schuttz, L. M. (2019). The Cultural Politics of English as an International Language. International Multilingual Research Journal, 13(1), 70-72. https://doi.org/10.1080/19313152.2018.1493905

Seidlhofer, B. (Ed.). (2003). Controversies in applied linguistics. Oxford, England: Oxford University Press. https://doi.org/10.1017/s0272263104313057

Seidlhofer, B. (2004). Research perspectives on teaching English as a lingua franca. Annual Review of Applied Linguistics, 24, 209-239. https://doi.org/10.1017/S0267190504000145

Seidlhofer, B. (2005). English as a lingua franca. ELT journal, 59(4), 339-341. https://doi.org/10.1093/elt/cci064

Selvi, A. F. (2013). Towards EIL teacher education: Exploring challenges and Potentials of MATESOL Programmes in the United States. In Zacharias, N. T., \& Manara, C. (Eds.). Contextualizing the pedagogy of English as an international language: Issues and tensions. Cambridge Scholars Publishing.

Sharifian, F. (Ed.). (2009). English as an international language: Perspectives and pedagogical issues (Vol. 11). Multilingual Matters. https://doi.org/10.21832/9781847691231

Sharifian, F. (2014). Cultural Linguistics Farzad Sharifian. In The Routledge handbook of language and culture (pp. 489-508). Routledge. https://doi.org/10.4324/9781315793993

Sharifian, F. (2017). English as an international language. The International Encyclopedia of Intercultural Communication. https://doi.org/10.1002/9781118묘783665.ieicc0027

Shin, J., Eslami, Z. R., \& Chen, W. C. (2011). Presentation of local and international culture in current international English-language teaching textbooks. Language, Culture and Curriculum, 24(3), 253-268. https://doi.org/10.1080/07908318.2011.614694

Shohamy, E. (2017). ELF and critical language testing. In J. Jenkins, M. Dewey, \& W. Baker (Eds.), The Routledge handbook of English as a lingua franca (pp. 583-593). Abingdon: Routledge. https://doi.org/10.4324/9781315717173-47

Si, J. (2019). English as a Lingua Franca: A New Approach for English Language Teaching in China? Chinese Journal of Applied Linguistics, 42(1), 30-45. https://doi.org/10.1515/CJAL-2019-0007

Smith, L. E. (1976). English as an international auxiliary language. RELC Journal, 7(2): 38-43. https://doi.org/10.1177/003368827600700205

Stern, H. H. (1983). Fundamental concepts of language teaching. Oxford: Oxford University Press. https://doi.org/10.3138/cmlr.40.3.462

Tan, K.H. \& Farashaiyan, A. (2016). Challenges in Teaching Interlanguage Pragmatics at Private EFL Institutes in Iran. Pertanika Journal of Social Sciences \& Humanities24 (S), 45-54

Tomak, B., \& Kocabas, P. (2013, May). The Perspectives of Turkish Prospective Teachers on "ELF" and Their 
Awareness of It in Their ELT Programs. In Proceedings of The Fifth International Conference of English as a Lingua Franca (pp. 183).

$\mathrm{Xu}, \mathrm{Z}$. (2017a). Developing meta-cultural competence in teaching English as an international language. In: Sharifian, F. (Ed.) Advances in Cultural Linguistics (pp. 703-20). Cham: Springer International Publishing AG. https://doi.org/10.1007/978-981-10-4056-6_31

Xu, Z. (2017b). Developing metacultural writing competence for online intercultural communication: implications for English language teaching. Teaching English as a Second or Foreign Language, 20(4), 1-9.

$\mathrm{Xu}, \mathrm{Z}$. (2018). Exploring English as an International Language: Curriculum, Materials and Pedagogical Strategies. RELC Journal, 49 (1), 102-118. https://doi.org/10.1177/0033688217753848 